\author{
JURNAL ABDIMAS \\ P-ISSN 2615-6849, E-ISSN 2716-070X

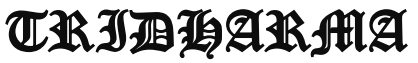 \\ Jurnal ABDIMAS Vol.2,No.3,Agustus 2021,Hal(102-107) \\ @Prodi Manajemen Fakultas Ekonomi Universitas Pamulang \\ Email: abdimasjurnal.unpam@ gmail.com Telp: (021) 741-2566
}

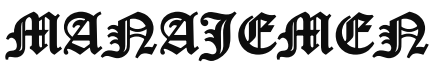

\section{MENCIPTAKAN UMKM TANGGUH MELALUI TERTIB LAPORAN KEUANGAN}

\author{
Suciati Muanifah $^{1)}$, Yenni Cahyani ${ }^{2)}$, Syamsul Mu'arif ${ }^{3)}$, Yulianto ${ }^{4)}$ \\ Fakultas Ekonomi dan Bisnis \\ Universitas Pamulang \\ dosen02242@unpam.ac.id,dosen02195@unpam.ac.id, \\ dosen02286@unpam.ac.id, dosen02238@unpam.ac.id
}

\begin{abstract}
ABSTRAK
Pengabdian Kepada Masyarakat dapat diartikan sebagai respon akademik masyarakat kampus atas kebutuhan, tantangan atau persoalan yang dihadapi oleh masyarakat, baik secara langsung maupun tidak langsung. Tujuan umum dari mendampingi UMKM yang tergabung dalam Persatuan UMKM Frozen Food. Persatuan UMKM Frozen Food Indonesia yang merupakan suatu lembaga yang fokus meningkatkan kapasitas UMKM yang bergerak dibidang Frozen Food sebagai upaya untuk meningkatkan kesejahteraan masyarakat dengan melakukan kegiatan pelatihan, seminar dan pendampingan.

Adapun bentuk kegiatan dalam pelaksanaan pengabdian kepada masyarakat dengan tema Pelatihan Akuntansi dan Pengelolaan Keuangan. Dengan para pengajar dan narasumber yang dilibatkan adalah para Dosen Program Studi Sarjana Akuntansi dari Universitas Pamulang. Hasil Pelaksanaan PKM yang dilakukan tanggal 09 April sampai 02 Mei 2021 adalah pemahaman UMKM yang didampingi mengenai pembuatan laporan keuangan dengan tema "Menciptakan UMKM Tangguh Melalui Tertib Laporan Keuangan". Beberapa permasalahan ditemukan permasalahan dalam pemahaman pelaku usaha kecil dalam pengelolaan keuangan dalam menjalakan usaha mereka, maka dari itu adapun tujuan dari Program Kemitraan Masyarakat (PKM) ini adalah; 1) Untuk meningkatkan Pengetahuan Pelaku Usaha Kecil Mengenai Pengelolaan Keuangan Sederhana, 2). Memberikan pelatihan mengenai Pengelolaan Keuangan Sederhana Untuk Usaha Kecil. Hasil kegiatan ini memperlihatkan bahwa pihak yang berkepentingan, seperti pemerintah, organisasi profesi akuntan, institusi pendidikan memotivasi, memfasilitasi dan mendukung organisasi UMKM mampu untuk menyusun laporan keuangannya sendiri.
\end{abstract}

\section{Kata kunci: Pelatihan Akuntansi, Laporan Keuangan, Tertib Laporan Keuangan ABSTRACT}

Community Service can be interpreted as the academic response of the campus community to the needs, challenges or problems faced by the community, either directly or indirectly. The general goal of assisting MSMEs who are members of the Frozen Food MSME Association. The Indonesian Frozen Food MSME Association, which is an institution that focuses on increasing the capacity of MSMEs engaged in Frozen Food as an effort to improve the welfare of the community by conducting training, seminars and mentoring activities.

The form of implementing community service with the theme of Accounting and Financial Management Training. The lecturers and resource persons involved were Lecturers of the Bachelor of Accounting Study Program from Pamulang University. The results of the PKM implementation carried out on April 09 to May 2, 2021 are the understanding of MSMEs related 


\section{JURNAL ABDIMAS \\ P-ISSN 2615-6849, E-ISSN 2716-070X

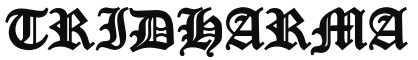 \\ Jurnal ABDIMAS Vol.2,No.3,Agustus 2021,Hal(102-107) \\ @ Prodi Manajemen Fakultas Ekonomi Universitas Pamulang \\ Email: abdimasjurnal.unpam@gmail.com Telp: (021) 741-2566}

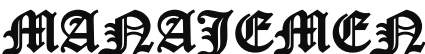

to the preparation of financial reports with the theme "Creating Resilient MSMEs Through Orderly Financial Reports". Some of the problems in understanding small business actors in financial management in running their businesses, therefore the objectives of this Community Partnership Program (PKM) are; 1) To increase Knowledge of Small Business Actors Regarding Simple Financial Management, 2). Providing training on Simple Financial Management for Small Businesses. The results of this activity indicate that interested parties, such as the government, professional accounting organizations, educational institutions, facilitate and support MSME organizations able to compile their own financial reports.

\section{Keywords: Accounting Training, Financial Reports, Orderly Financial Reports}

\section{PENDAHULUAN}

Usaha Mikro Kecil dan Menengah (UMKM) merupakan salah satu penggerak perekonomian rakyat yang sangat tangguh dan memberikan kontribusi signifikan dalam memacu perekonomian di Indonesia. Di Indonesia perkembangan UMKM sangatlah pesat, menurut data yang dikumpulkan oleh Kementerian Koperasi dan UMKM adalah sebagai berikut:

a. 2014 berjumlah 57.895 .721 unit

b. 2015 berjumlah 59.262 .772 unit dengan pangsa $98 \%$

c. 2016 berjumlah 61.651 .117 unit dengan pangsa $99 \%$

d. 2017 berjumlah 62.922.617 unit dengan pangsa $99,99 \%$

Berdasarkan data Lembaga Ilmu Pengetahuan Indonesia (LIPI), bila pandemi tak kunjung usai, 85,42 persen UMKM hanya akan mampu bertahan selama satu tahun. Sementara itu, pelaku UMKM yang masih bertahan juga tak luput dari ancaman kesehatan yang terus menghantui. Setiap hari, mereka melayani dan bertransaksi dengan banyak orang silih berganti. Beberapa pelaku UMKM mengatakan bahwa tanpa akuntansi pun perusahaan tetap berjalan lancar dan selalu memperoleh laba. Banyak pelaku UMKM merasa bahwa perusahaan mereka berjalan normal namun sebenarnya UMKM tersebut tidak mengalami perkembangan.

Banyak UMKM yang tidak bertahan lama dikarenakan pengelolaan keuangan yang tidak tepat. Pengelolaan keuangan yang tidak tepat juga mengakibatkan penetapan harga pokok penjualan yang ditetapkan tidak tepat. Dampaknya adalah perusahaan akan mengalami kerugian dan mengakibatkan kebangkrutan. Oleh karena itu pengelolaan keuangan menggunakan akuntansi adalah hal yang sangat diperlukan sebagai solusi masalah manajemen keuangan usaha.

Berdasarkan permasalahan tersebut, perlu diadakan kegiatan pelatihan bagi pelaku UMKM dalam hal mengelola keuangan. Program pelatihan yang ditawarkan berupa pelatihan akuntansi sederhana bagi UMKM. Akuntansi yang diajarkan adalah Pengelolaan Keuangan sederhana yang disesuaikan dengan keadaan di UMKM namun tidak meyimpang dari standar dan peraturan yang ada. Pelatihan ini ditujukan bagi pelaku UMKM Frozen Food yaitu Ibu Lian yang memiliki usaha memproduksi air minum segar dan kue kering.

Berdasarkan dari perihal yang peneliti paparkan sebelumnya, bahwa para pelaku UMKM Frozen Food Indonesia belum memiliki kesadaran para pelaku UMKM tentang tata kelola 
JURNAL ABDIMAS

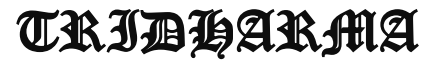

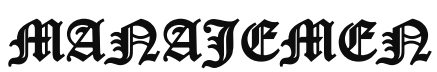

P-ISSN 2615-6849, E-ISSN 2716-070X

Jurnal ABDIMAS Vol.2,No.3,Agustus 2021,Hal(102-107)

@ Prodi Manajemen Fakultas Ekonomi Universitas Pamulang

Email: abdimasjurnal.unpam@ gmail.com Telp: (021) 741-2566 keuangan usaha kecil yang sesuai stanar akuntansi sederhana yang khususnya mengenai manajemen keuangan dan manajemen bank dan pengetahuan mengenai bank dan non lembaga keuangan. Target Luaran Para pelaku UMKM dapat memiliki pengetahuan tentang Akuntansi UMKM yang sederhana, manajemen umum, dan bank dan lembaga keuangan. Menanamkan kesadaran para pelaku usaha kecil menengah tentang arti pentingnya Akuntansi UMKM yang sederhana dan manajemen umum, dan bank dan lembaga keuangan. Terciptanya buku pedoman dan standarisasi tata kelola keuangan usaha bagi para pelaku UMKM Sebagai langkah awal dalam rangka melaksanakan penelitian lanjutan dan program pengabdian masyarakat selanjutnya.

Tujuan Pengabdian Kepada Masyarakat ini dilakukan untuk memberikan pengetahuan dan pemahaman mengenai Akuntansi dan Pengelolaan Keuangan, memberikan pengetahunaan tentang cara menyusun Laporan Keuangan Sederhana., dan memberikan pelatihan dan pemahaman Laporan Keuangan sebagai alat menciptakan disiplin melalui tertib laporan keuangan. Sedangkan manfaat pengabdian kepada masyarakat ini untuk memberikan pengetahuan bagi para pelaku UMKM pada umumnya mengenai pentingnya Akuntansi dan Pengelolaan Keuangan, memberikan pengetahuan bagi para pelaku UMKM pada umumnya dan UMKM Frozen Food secara khusus mengenai cara menyusun Laporan Keuangan Sederhana, dan memberikan pelatihan dan pemahaman laporan keuangan sebagai alat untuk menciptakan disiplin melalui tertib laporan keuangan.

Laporan keuangan adalah hasil dari proses akuntansi yang menyediakan informasi keuangan suatu perusahaan yang bermanfaat bagi pihak-pihak yang berkepentingan didalam pengambilan keputusan ekonomi. Tujuan laporan keuangan adalah memberikan informasi posisi keuangan, kinerja keuangan, dan arus kas entitas yang bermanfaat bagi sebagian besar kalangan pengguna laporan dalam pembuatan keputusan ekonomi. SAK EMKM ditujukan untuk digunakan oleh entitas mikro, kecil, dan menengah. EMKM adalah entitas tanpa akuntabilitas publik yang signifikan, seperti yang diatur dalam Standar Akuntansi Keuangan Entitas Tanpa Akuntabilitas Publik (SAK ETAP), yang memenuhi definisi dan kriteria usaha mikro, kecil, dan menengah sebagaimana diatur dalam peraturan perundang-undangan yang berlaku di Indonesia, setidak-tidaknya selama 2 tahun berturut-turut. Penyajian wajar laporan keuangan mensyaratkan entitas untuk menyajikan informasi yang relevan, representative tepat, keterbandingan, dan keterpahaman.

\section{METODE PENELITIAN}

Khalayak sasaran yang dipilih pada kegiatan PKM ini adalah UMKM yang berada dibawah naungan Persatuan UMKM Frozen Food Indonesia sebanyak 13 UMKM yang dibagi kepada beberapa kelompok Tim Pengabdi. Penetapan sasaran ini merupakan suatu upaya yang dilakukan untuk memecahkan berbagai permasalahan yang dihadapi oleh UMKM dibawah naungan Persatuan UMKM Frozen Food Indonesia.

Pelaksanaan pengabdian dibagi menjadi beberapa tahap yaitu : Tahap Persiapan dilakukan dengan mengumpulkan seluruh pelaku UMKM beserta seluruh Tim pengabdi dalam acara seminar dengan tema "Pengabdian Kepada Masyarakat : 
JURNAL ABDIMAS

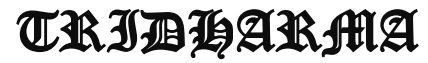

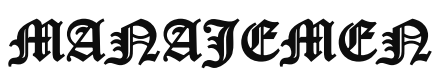

P-ISSN 2615-6849, E-ISSN 2716-070X

Jurnal ABDIMAS Vol.2,No.3,Agustus 2021,Hal(102-107)

@ Prodi Manajemen Fakultas Ekonomi Universitas Pamulang

Email: abdimasjurnal.unpam@ gmail.com Telp: (021) 741-2566
"Menciptakan UMKM Tangguh Melalui Tertib Laporan Keuangan “" yang diselenggarakan melalui aplikasi zoom pada Jumat 9 April 2021.

Kegiatan pengabdian kepada masyarakat ini dilakukan secara online via Zoom dengan bertahap, tahap pertama dilakukan sharing discussion terkait permasalahan yang dihadapi oleh mitra, tahap kedua dilakukan pertemuan online via zoom dengan memberikan pelatihan terkait pembuatan laporan keuangan sederhana, dan tahap berikutnya dilakukan secara langsung dengan mendampingi dan memberikan beberapa contoh transaksi usaha dagang dan produksi kepada mitra PKM yaitu ibu Lian.

Dalam rangka mencapai tujuan yang tercantum di atas, maka pelaksanaan kegiatan pengabdian masyarakat ini dilaksanakan dengan beberapa metode, yaitu ceramah, tutorial, dan diskusi.

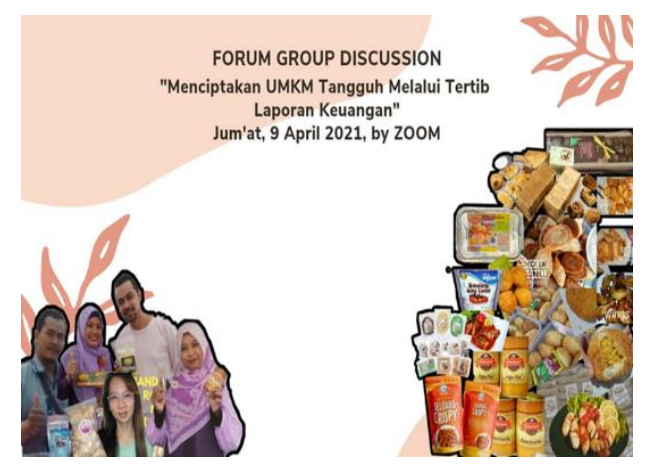

\section{HASIL DAN PEMBAHASAN}

Kegiatan pelatihan pengelolaan keuangan bagi UMKM , dilakukan online dan offline sesuai jadwal yang telah disepakati antara pihak mitra dan pihak penyelenggara PKM. Pelaksanaan kegiatan ini setelah dilakukan beberapa kali koordinasi dengan pihak UMKM tentang materi dan peserta pengabdian kepada masyarakat yang menjadi target pelatihan, waktu pelaksanaan PKM serta tempat yang layak sebagaimana tertuang dalam dokumen rencana kegiatan. Pencapaian Tim Pelaksana dalam Program Kemitraan Masyarakat, diantaranya: dilakukannya survey ke lokasi para pelaku usaha, guna mendapatkan keadaan awal kegiatan usaha yang sedang dijalaninya. Dari hasil wawancara, maka Tim Pelaksana bekerjasama dengan para mitra untuk melaksanakan pelatihan dalam hal penyusunan laporan keuangan dengan teknik pembukuan sederhana, yang diharapkan mampu menjawab permasalahan yang dihadapi baik itu mitra ataupun pelaku usaha lainnya.

Tim Pelaksana juga

berkoordinasi dengan para mitra untuk mempermudah pelaksanaan pelatihan. Adapun materi yang diberikan, antara lain: a) Pentingnya Kewirausahaan bagi Pelaku Usaha UMKM, b) Pentingnya Manajemen Keuangan bagi Pelaku Usaha UMKM, c) Teknik Pengelolaan Keuangan Sederhana Sederhana dalam menyusun laporan keuangan usaha. Penyampaian materi oleh tim PKM dilakukan dengan sistem ceramah.

Tahap pengamatan secara mendalam dan komprehensif (monitoring) dan evaluasi pelaksanaan kegiatan penyuluhan terhadap para peserta merupakan tolok ukur untuk mengetahui capaian atau terdapatnya peningkatan pengetahuan, pemahaman dan perilaku (kompetensi) peserta. Kegiatan monitoring partisipasi peserta dilihat sejak dimulainya sosialisasi pelatihan sampai pada penutupan pelatihan. Dalam tahap ini, setiap materi yang disampaikan oleh tim PKM mendapat respon aktif dari seluruh peserta dengan perhatian yang optimal. Evaluasi program dilakukan untuk mengetahui sejauh mana ketercapaian pelaksanaan kegiatan pendampingan dan pelatihan. Evaluasi kegiatan 


\section{JURNAL ABDIMAS \\ P-ISSN 2615-6849, E-ISSN 2716-070X

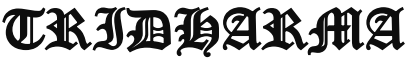 \\ Jurnal ABDIMAS Vol.2,No.3,Agustus 2021,Hal(102-107) \\ @Prodi Manajemen Fakultas Ekonomi Universitas Pamulang \\ Email: abdimasjurnal.unpam@ @mail.com Telp: (021) 741-2566}

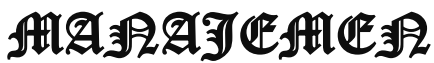

dilakukan selama proses kegiatan berlangsung, yaitu pada saat peserta kegiatan mengikuti pendampingan. Selain itu, melakukan wawancara yaitu memberikan pertanyaan yang terkait dengan pelaksanaan pendampingan secara individu.

Dengan adanya evaluasi ini, tim pelaksana kegiatan pendampingan dan pelatihan dapat meyimpulkan bahwa kegiatan pendampingan dan pelatihan dapat menambah dan meningkatka

pengetahuan para pelaku UMKM. Foto-foto kegiatan saat melaksanakan pelatihan ini yaitu:

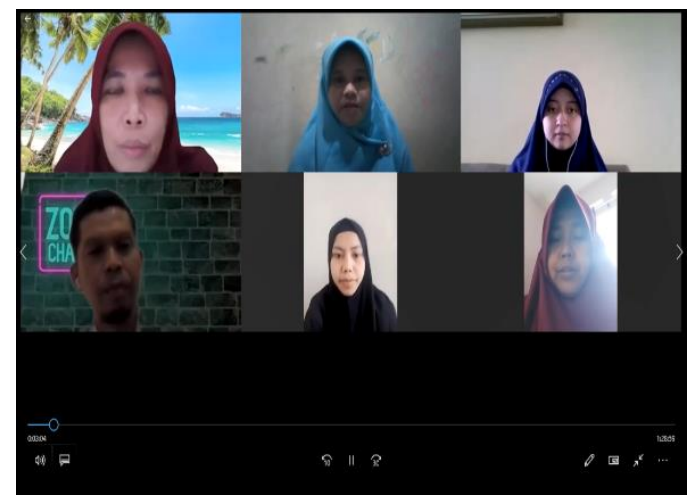

Gambar Foto Kegiatan Persiapan Pengabdian Kepada Masyarakat

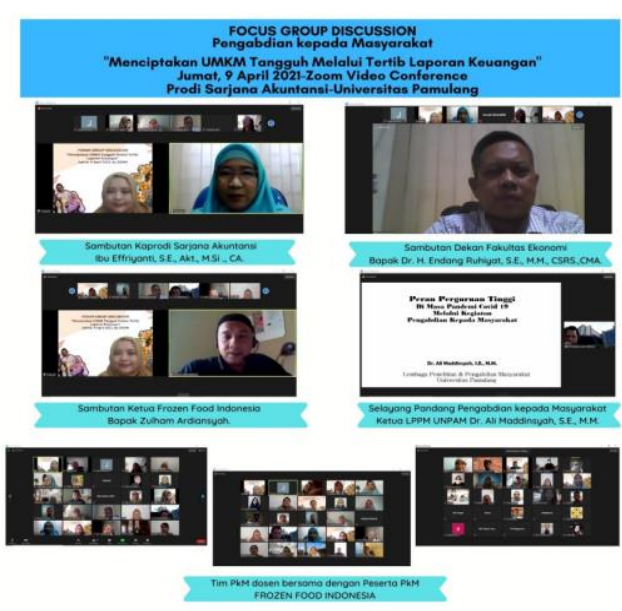

Gambar Sambutan dari Dekan

Fakultas Ekonomi dan Bisnis, Ketua PRODI Sarjana Akuntansi dan Ketua LPPM UNPAM
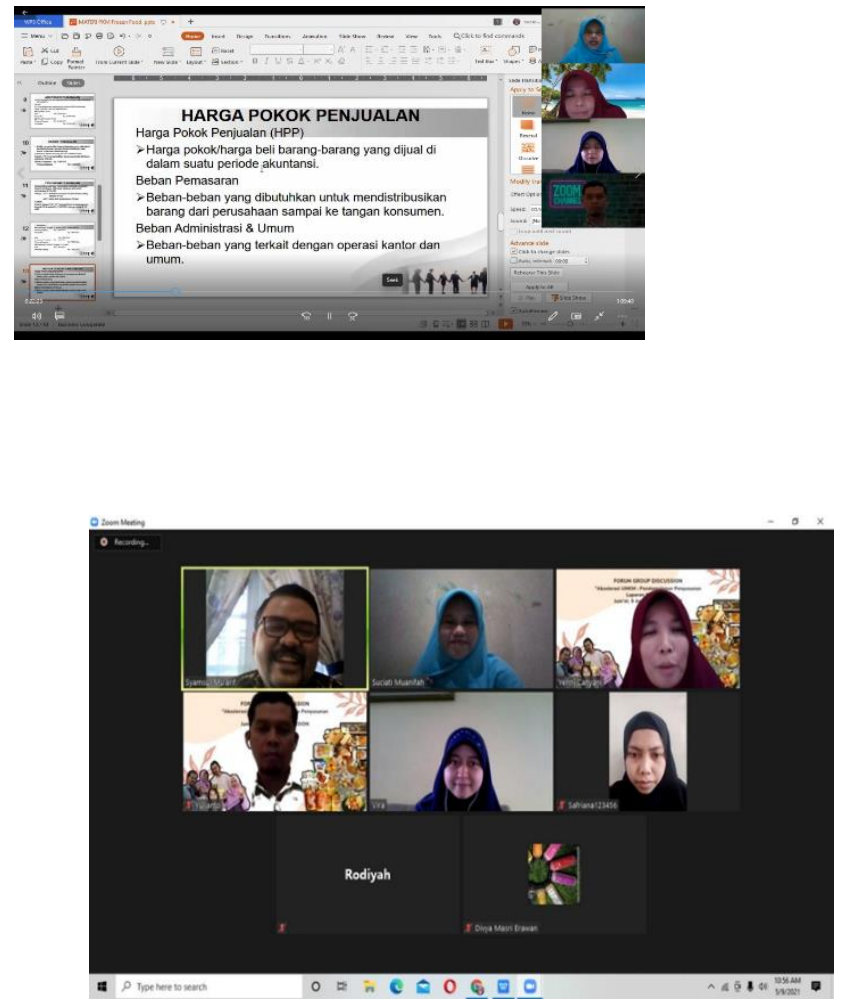

Gambar Perkenalan, wawancara dan pendampingan pembuatan 


\section{JURNAL ABDIMAS P-ISSN 2615-6849, E-ISSN 2716-070X

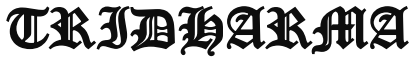 Jurnal ABDIMAS Vol.2,No.3,Agustus 2021,Hal(102-107) \\ @ Prodi Manajemen Fakultas Ekonomi Universitas Pamulang \\ Email: abdimasjurnal.unpam@gmail.com Telp: (021) 741-2566}

\section{AntA}

\section{KESIMPULAN}

\section{laporan keuangan kepada UMKM ibu Marlian}

Kesimpulan yang diperoleh kegiatan pengabdian masyarakat ini adalah perserta dapat memahami pentingnya akuntansi dan laporan keuangan dengan mengelompokkan aset UMKM dengan asset pribadi melalui tertib laporan keuangan atau membuat catatan sederhana, peserta dapat melakukan pengelolaan keuangan dengan adanya penyusunan laporan keuangan secara sederhana, dan peserta sudah dapat mengetahui laba atau rugi yang dihasilkan dari usahanya melalui penyusunan laporan keuangan sehingga dapat menciptakan UMKM tangguh dan disiplin.

\section{REFERENSI}

D. Hapsari, A. Hasanah, "Model Pembukuan Sederhana Bagi Usaha Mikro d i Kecamatan Kramatwatu Kabupaten Serang," Jurnal Akuntansi, 4 (2), 36, (2017). Griffin, Ricki W dan Ronal J Ebert. 2017. Bisnis Edisi 8. Jakarta: Erlangga.

Ikatan Akuntan Indonesia. 2017. Standar Akuntansi Keuangan: Standar Akuntansi Keuangan. IAI

Pasaribu, V. L. D., Agrasadya, A., Shabrina, N., \& Krisnaldy, K. (2020). Menjadi Enterpreneur Muda Yang Memiliki Jiwa Leadership Untuk Menghadapi Masa Depan. Abdi Laksana: Jurnal Pengabdian Kepada Masyarakat, 1(1).

Pasaribu, V. L. D., Susanti, F., \& Hartuti, E. T. K. (2019). Memotivasi Siswa dan Siswi SMK Letris Indonesia di Dalam Menentukan Pilihan Untuk

\begin{tabular}{|c|c|}
\hline $\begin{array}{l}\text { Melanjutkan } \\
\text { Bekeria }\end{array}$ & $\begin{array}{ll}\text { Pendidikan } & \text { Atau } \\
\text { Setelah } & \text { Lulus }\end{array}$ \\
\hline ekolah. Jur & Pengabdia \\
\hline
\end{tabular}

Pasaribu, V. L. D., Sulaiman, S., Sutiman, S., Thaharudin, T., \& Purnomo, B. Y. (2020). Pengenalan Letak Posyandu Terdekat Dikelurahan Pisangan Dengan Manajemen Pemasaran Revolusi 4.0 Untuk Meningkatkan Pengetahuan Masyarakat Letak Dan Fungsi Posyandu Terdekat Pada Kelurahan Pisangan. Dedikasi Pkm, 1(1), 105110.

Pasaribu, V. L. D., Oktrima, B., Prabowo, B., Arianto, N., \& Haryoko, U. B. (2020). Progam Pendampingan Dan Penyelenggaraan Pendidikan Anak Pada Usia Dini Terhadap Prestasi Belajar Dilingkungan Rt $020 \mathrm{Rw}$ 009. Kel Giri Peni. Kec Wates. Yogyakarta. Jurnal Lokabmas Kreatif, 1(1), 71-75.

Pasaribu, V. L. D., Jannah, M., Fazar, M., Putra, S. P., Monalisa, M., \& Sofa, M. (2021). MENINGKATKAN PRODUKTIVITAS USAHA DIMASA PANDEMI PADA IBU PKK RT 004/003 KELURAHAN SAWAH BARU CIPUTAT, TANGERANG SELATAN. Abdi Laksana: Jurnal Pengabdian Kepada Masyarakat,2(2), 295301.

Pasaribu, V. L. D., Yuniati, H. L., Pranata, R., Sembayu, R., Purba, S. M., \& Nurbayani, T. T. A. (2021). MANAJEMEN KEUANGAN 


\section{JURNAL ABDIMAS P-ISSN 2615-6849, E-ISSN 2716-070X

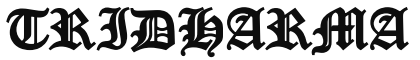

\section{UNTUK MENGHADAPI DAN BERTAHAN DI ERA COVID \\ 19. Jurnal Abdimas Tri Dharma Manajemen, 2(2), 12-18.}

Pasaribu, V. L. D., Dwiyatni, A., Sabina, C., Ridwan, M., Gunawan, D. D., \& Noviani, B. C. (2021). EVALUASI PENERAPAN 3M DIMASA PANDEMIC COVID 19. Jurnal Abdimas Tri Dharma Manajemen, 2(2), 54-60.

Pasaribu, V. L. D., Syafei, A. N., Farhan, A., Aufaizah, A., Irani, C., \& Firtiayani, S. R. (2021). PENGARUH DISPLIN PROTOKOL KESEHATAN TERHADAP PENCEGAHAN PENULARAN VIRUS COVID19. Jurnal Abdimas Tri Dharma Manajemen, 2(2), 91-98.

Pasaribu, V. L. D., Septiani, F., Rahayu, S., Lismiatun, L., Arief, M., Juanda, A., ... \& Rahim, R. (2021). Forecast Analysis of Gross Regional Domestic Product based on the

\author{
Linear Regression Algorithm \\ Technique.
}

Priadi, A., Pasaribu, V. L. D., Virby, S., Sairin, S., \& Wardani, W. G. (2020). Penguatan Ekonomi Kreatif Berbasis Sumber Daya Desa Dikelurahan Rempoa. Abdi Laksana: Jurnal Pengabdian Kepada Masyarakat, 1(3), 356-35

Surjono, Prasetio Ariwibowo, Mima Nizma. 2018. Penerapan Standarisasi laporan keuangan UMKM bagi Pengusaha Kecil Menengah untuk meningkatkan Kinerja Usaha.. Vol. 01 No. 03, September-Desember 2018. Jurnal PKM: Pengabdian kepada Masyarakat.

S. Warsono, "Akuntansi UMKM Ternyata Mudah Dipahami dan Dipraktikkan," Yogyakarta: Asgard Chapter, 2014.

V. Rivai, "Commerical Bank Management: Manajemen Perbankan dan Teori ke Praktik," Edisi 1. Cetakan 1. Jakarta: Rajawali Pers, 2013.

www.viva.co.id 